\title{
Food security problems in various income groups of Kakamega County
}

\begin{abstract}
Poverty and hunger are common in Kenya especially in arid and semi-arid lands that cannot support crops and are also overgrazed thereby yielding low incomes, ${ }^{1}$ and in urban low income dwellings. Indicators of food insecurity and malnutrition such as proportion of the poor in the population, those requiring food assistance and anthropometric measurements have through the years shown that large proportions, ${ }^{2}$ about half the population of Kenya are food insecure. Among the affected, around 3.5million go hungry or are malnourished. Increasing income promotes consumption of diverse foods and facilitates change in diets from basic staples such as maize to foods that require less preparation fruits and processed foods. This research was carried out to assess consumption of foods and characteristics of various income groups and determine factors that cause food insecurity. Three Kakamega housing estates were selected to represent low income group, medium income group, and high income group. These estates are, respectively, Lurambi, Milimani and Kefinco. Monthly income by the low income, medium income and high income households were, respectively, KES $\leq 14000$ (US $\$ 140$ ), 14001 to 56000 (US $\$ 140$ to 560 ) and $\geq 56000$ (US $\$ 560$ ). In each estate, a sample of 130 households was studied. The average household had 5 people.ugali (thick porridge) is the main staple food and was consumed by $88 \%$ of the households, while vegetables were consumed by $92 \%$. Meat was consumed by $46 \%$ of the households and fruit products by $17 \%$. It was found that the low income group could not purchase adequate food and amounts they consumed did not meet the FAO recommended levels for foods and nutrients. ${ }^{3}$ Low incomes and poverty are the main cause of food insecurity in Kenya. ${ }^{4}$ It is recommended that there be better education for employment, irrigation of crops especially in arid and semi arid lands for food production ${ }^{5}$ as well as improved health status and sanitation to enable earning of high income to reduce poverty and consequently enhance food security and nutrition. ${ }^{6}$
\end{abstract}

Keywords: poverty, income, irrigation, food security
Volume 7 Issue I - 2017

\author{
John O Ombogo \\ Masinde Muliro University of Science and Technology, Kenya \\ Correspondence: John $\bigcirc$ Ombogo, Masinde Muliro University \\ of Science and Technology, P.O Box 190-50100, Kakamega, \\ Kenya, Tel +2547I5495693, Email johnwesely72@gmail.com
}

Received: November 27, 2016 | Published: September 06, 2017

\section{Introduction}

Food security, at the individual, household, national, regional and global levels [is achieved] when all people, at all times, have physical and economic access to sufficient, safe and nutritious food to meet their dietary needs and food preferences for an active and healthy life. Poverty is the underlying cause of food insecurity, while food insecurity causes malnutrition. Food insecurity is a challenge for Kenya that endorsed the Millennium Development Goals in 2000, which include Goal 1 as the eradication of poverty and hunger. This research was carried out to map out foods consumption per capita in households of various income levels. The "minimum dietary energy requirement" for each person as stipulated by the UN Food and Agriculture Organization (FAO) is just below 2,000 kilocalories per day. ${ }^{8}$ In Kenya, the poverty line is determined by expenditure required to purchase the food basket that yields a minimum 2,250kcal per adult equivalent per day in addition to non food needs.

Dietary recommendations for Kenya include daily per capita consumption of cereals maize or wheat products and or rice $(500 \mathrm{~g})$, green leafy vegetables $(50-150 \mathrm{~g})$, meat or fish $(100 \mathrm{~g})$, carrots $(100 \mathrm{~g})$ and fruit $(100 \mathrm{~g})$, oil $(15-25 \mathrm{~g})$, salt $(10 \mathrm{~g})$, milk or milk in tea and eggs. National food balance sheet in Kenya, ${ }^{9}$ in 2005 provided $2256 \mathrm{kcal}$ per capita per day. Among foods that contributed to this were: maize products 212 grams containing $672 \mathrm{kcal}$ and $16 \mathrm{~g}$ protein, wheat products $76.4 \mathrm{~g}$ with $207 \mathrm{kcal}$ and $6 \mathrm{~g}$ protein, dry beans $28.8 \mathrm{~g}$ with $98 \mathrm{kcal}$ and $6 \mathrm{~g}$ protein, meat $42.5 \mathrm{~g}$ with $80 \mathrm{kcal}$ and $6 \mathrm{~g}$ protein, fish $6.9 \mathrm{~g}$ with $5 \mathrm{kcal}$, vegetables $68 \mathrm{~g}$ with $15 \mathrm{kcal}$, and fruit $16 \mathrm{~g}$ with $100 \mathrm{kcal}$.

As a country prospers, its diet becomes more varied; higher consumption of animal protein foods, fats, and oils increases the energy level of the diet and protein utilization. Animal proteins contain more of essential amino acids than plant proteins and have, therefore, higher nutritive value. In Kenya, the poor have per capita income of US $\$ 1$ or less a day. For an average household with five persons the household income of the poor is KES 12,245 ( US \$122.5) or less per month, low income household earns KES 14000 (US \$140) and below per month, middle income is KES 14001 to 56000 (US\$140 to 560) and high income is above KES 56,000pm (US \$560).

The Kenya Demographic and Health Survey, ${ }^{10}$ showed anthropometric indicators of malnutrition among children aged five years as: $20.2 \%$ of children were underweight, $4 \%$ were severely underweight, $33 \%$ of male and $28 \%$ of female children were stunted, and $6.1 \%$ were wasted. According to anthropometric height and weight deviations from mean of population, a -2 standard deviation from population means is considered moderately affected and -3 is severely affected by malnutrition. In $2007,{ }^{11}$ about $56 \%$ of Kenyans were poor and hence their households had no income to afford basic needs including food of 2250 kilocalories per adult equivalent per day. ${ }^{12}$ According to provinces, poverty in Nairobi was $29.5 \%$, Central 
$31.4 \%$, Nyanza 46.1\%, Rift Valley 49.5\%, Eastern 45.2\%, Western $51.1 \%$, Coast $63.5 \%$ and North Eastern $66.5 \%$. Between February and September 2009, Kenyans requiring food assistance numbered 2.6 million out of 38.6million people. ${ }^{13}$ On August 20, 2009, the Kenya Food Security Steering Group (KFSSG) ${ }^{14}$ projected the number of people requiring emergency food assistance between September 2009 and February 2010 to be 3.8 million. In addition, the report identified approximately 2.5 million chronically food insecure individuals located in urban areas, 1.5 million primary school students in droughtaffected areas, 100,000 persons displaced by post-election violence and 2million rural HIV/AIDS patients as food insecure and in need of humanitarian assistance countrywide.

In 2011 the number of hungry Kenyans was 3.5million. In July 2011 deaths caused by starvation elicited organizations such as Kenya Red Cross Society, Safaricom Mobile Phone Company , Kenya Commercial Bank and the Media to launch the Kenyans for Kenya appeal for donations at which 500million KES was raised in the first 10 days in July 2011. By end of August 2011, ${ }^{15}$ about 700million KES (US \$7million) had been raised to buy food for the affected especially school children and the vulnerable, and also disburse funds to those at risk in arid and semi arid parts of northern Kenya and other affected rural and urban areas. According to FAO, the main factors that influence poverty and food insecurity at national, community or individual levels are: land and water quality, political structures, government policies and services, exchange rates, fuel, farm equipment and inputs, agricultural production, research, development and processing, employment, culture, income, storage facilities, money and credit, transport, resource management, advertising, water and sanitation, healthcare, prepared food, and family food distribution and education since women's secondary education correlates with almost 43 per cent in reduction of child malnutrition in developing countries. ${ }^{16}$

In agriculture, the climate, rainfall and/ or irrigation for adequate soil moisture are necessary for growing crops. The extension providers in agricultural industry include the Government, NGOs, and community based organizations. However, most of the extension service providers, in carrying out their activities often do not consider the priority demands of the farmers. Kenya Red Cross has proved that by giving families water pumps and/or greenhouses for irrigation they become food secure. Poor people who are affected by hunger and limited understanding lack self initiative to utilize resources in development opportunities and, therefore, make no strategies for sustainable productivity but attack and deplete available resources from the environment and from other persons.

Their strategies to cope with poverty include overgrazing, deforestation and overexploitation for fuel wood which result in soil degradation and reduced rainfall, making and selling charcoal, seeking employment, child labour, child marriages, begging, and selling assets like land and cows to buy food. Other coping strategies are; abandoning responsibility of paying debts, trespassing, engaging in crime, corruption, stealing, prostitution, selling voters cards, seeking financial assistance from government or non-government organizations, migrating and waiting for food aid or death by starvation. These strategies are not self sustaining and perpetuate vicious cycle of poverty. ${ }^{17}$

In Africa, urbanization has occurred in an environment of consistent economic decline. ${ }^{18}$ Moreover, conflicts, drought, and rural economic decline have contributed to rapid rural to urban migration of millions of people seeking a chance at a better life. Over 70 per cent of the urban population in sub-Saharan Africa lives in slum like conditions,${ }^{19}$ with little or no access to basic services. In other parts of the world, urban transition has been linked to industrialization and greater economic opportunities. Urbanization and increasing incomes promote consumption of diverse foods and facilitate change in diets from basic staples such as maize to cereals that require less preparation like wheat products and to fruits and processed foods. Dietary diversity is associated with child nutritional status and growth as seen in Kenya. However, urbanization is also associated with negative changes of nutrition transition that include quantitative and qualitative shifts in the structure of diets away from staples like roots and tubers towards more livestock products and vegetable oils, with higher energy dense diets, more fat, added sugars in foods, greater saturated fat intake (mostly from animal sources), reduced intakes of complex carbohydrates and dietary fibre, and reduced fruit and vegetable intakes.

\section{Materials and methods}

This study was a cross-sectional survey of household food consumption patterns in various income groups of Kakamega, by use of a questionnaire. Households' food consumption survey The estates Lurambi, Milimani and Kefinco were purposely selected since they, respectively, represent different income groups based on household income as follows: the low income group earns $\leq$ KES 14000 per household per month, middle income group is KES 14001 to 56000 and high income group with KES 14001 to 56000 per month. During the survey, ${ }^{20}$ US $\$ 1$ was equivalent to KES 100 . Housing estates are rated according to household residence plot size, respectively, with Low income households being situated on $\leq 1 / 8$ acre, Middle on $1 / 8$ to $1 / 4$ acre, and High income households on $1 / 2$ to $3 / 4$ acre ( $1 / 5$ to $3 /{ }_{10}$ hectare). The target population of Kakamega residents totaled 1million. ${ }^{21,22}$

The sample size of households in the survey was determined by formula of Medicines Sans Frontiers (1995), by which the desired sample size $\mathrm{s}$ where $\mathrm{t}=$ standard deviate $\mathrm{z}$ set at $2 ; \mathrm{p}=$ estimate proportion of the 1 whole, or percent of individuals with the particular characteristic in consideration is set at $0.6 ; \mathrm{d}$ is degree of accuracy to involve extreme ends set at 0.05 ; The calculated sample size was 390 households. In each of the purposely selected estates/clusters representing particular income groups, a sample of 130 households was randomly selected for the study. The table of random numbers was used to select a random first household in the estate among the first 5 households by the main entrance of the estate. From then on, a third of households were sequentially picked until 130 households were included. A structured questionnaire was used to collect the data on food consumption and other characteristics of household members.

The researcher and trained assistants made initial visits to the sampled households and explained the purpose of the survey to each household head and other members of the household. Thereafter, the researcher and assistant made visits to each selected household once every 24 hours for seven (7) days and interviewed the housewife or the person responsible for food preparation and serving in the household. The researcher asked the respondent to describe all the dishes made in the house the previous day and explain the ingredients and amount consumed. The stated weights of food ingredients were randomly checked by the researcher using a balance and also with the supermarket prices and weights. 


\section{Results}

Food consumption patterns by households in various income groupsugali, which is a thick porridge made from maize flour is the main staple carbohydrate food consumed by $88 \%$ of the households at least 4 times in the week. Green vegetables were consumed by $92 \%$ and meat, a main protein source, was eaten by $46 \%$ of the sample households at least 4times in seven days. In Kenya, the concept of balanced diet means a diet that includes a carbohydrate staple, vegetable and a protein source. Foods eaten by the $46 \%$ of all population at least 4 times a week were 13 foods which are: tea, sugar, milk, bread, thin porridge with lemon (uji), ugali, green leafy vegetables, beef, cooking oil or fat, salt, carrot, onion and tomato. Among the low income households, $46 \%$ ate 12 foods at least four times in seven days; the meals includedugali, green vegetables and beans but left out beef, milk, bread and carrots as well as eggs. Among middle income households, $46 \%$ consumed 15 foods at least four times in a week, which included the thirteen foods listed above and also beans or green grams and carrots.

Forty six percent of the high-income group consumed 17 foods which included beef, eggs and carrots at least 4 times in a week. Eggs were eaten by $43 \%$ of all households. Eggs were commonly eaten by both the low-income and middle-income groups as the main side dish forugali during lunch or supper whereas in high-income group, eggs are consumed as part of breakfast. Fruits such as bananas, oranges and mangoes were eaten at least four times a week by only 26 percent of the households, while processed fruit drinks were consumed by $17 \%$ of the households. Carbonated soft drinks were also consumed at home at least four times in a week by $12 \%$ of households mainly in the high-income group. In this present survey, the mean amount of specific foods consumed per capita is in Table 1.

Table I Intake of foods in $\mathrm{g}$ by individuals of various income groups per day

\begin{tabular}{|c|c|c|c|}
\hline \multirow{2}{*}{ Food } & \multicolumn{3}{|c|}{ Food intake per capita per day in $\mathrm{g}$} \\
\hline & Low income & Middle income & High income \\
\hline Sugar & 10 & 30 & 30 \\
\hline Milk & 30 & 100 & 100 \\
\hline Bread & 8 & 100 & 100 \\
\hline Margarine Fat & 15 & 15 & 20 \\
\hline Wheat-Flour-Dough - Fried-Bun or Chapati & 40 & 50 & 80 \\
\hline Thin Porridge of Either Maize, Millet or Oat & 200 & 160 & 160 \\
\hline Eggs & 25 & 40 & 60 \\
\hline Maize Flour (Ugali) & 300 & 300 & 220 \\
\hline Rice & 3 & 80 & 80 \\
\hline Potato & 45 & 45 & 45 \\
\hline Pumpkin & 80 & 50 & 0 \\
\hline Beans/Gram & 20 & 25 & 35 \\
\hline Green Leafy Vegetables & 97 & 97 & 97 \\
\hline Beef & 15 & 50 & 100 \\
\hline Chicken & 2 & 40 & 80 \\
\hline Fish & 5 & 20 & 40 \\
\hline Cooking Fat or Oil & 20 & 25 & 30 \\
\hline Salt & 7 & 7 & 7 \\
\hline Carrot & 1 & 20 & 30 \\
\hline Tomato & 10 & 10 & 35 \\
\hline Carbonated Soft Drink & 0 & 246 & 246 \\
\hline Fruit /Banana or Orange or Mango & 70 & 85 & 95 \\
\hline Fruit Soft Drink & $18 \mathrm{ml}$ & $16 \mathrm{ml}$ & $33.5 \mathrm{ml}$ \\
\hline
\end{tabular}


The significance difference in consumption by various income groups is in Table 2. Values among groups differ significantly at $\mathrm{p} \leq 0.05$. The energy content ( $\mathrm{kcal}$ ), vitamin Aug retinol equivalent, and vitamin $\mathrm{C}$ in each amount of food were calculated based on equivalent values per gram as provided by USDA. It was found that the average consumption per capita by low income group included $1915 \mathrm{kcal}$, $335 \mathrm{ug}$ vitamin A and $55 \mathrm{mg}$, vitamin C; per capita consumption in middle income group included $2653 \mathrm{kcal}, 627 \mathrm{ug}$ vitamin A and $81 \mathrm{mg}$, vitamin $\mathrm{C}$; and per capita consumption in high income group included $2958 \mathrm{kcal}, 828 \mathrm{ug}$ vitamin A and $167 \mathrm{mg}$, vitamin C.

Table 2 Intake of particular food groups in grams by individual in the various income groups per day

\begin{tabular}{|c|c|c|c|c|c|}
\hline Foods & $\begin{array}{l}\text { Low income } \\
\text { group }\end{array}$ & $\begin{array}{l}\text { Middle } \\
\text { income group }\end{array}$ & $\begin{array}{l}\text { High } \\
\text { income } \\
\text { group }\end{array}$ & $\begin{array}{l}\text { Total } \\
\text { mean } \pm \text { standard } \\
\text { deviation }\end{array}$ & Significant value for $P$ \\
\hline Cereals & 540 & 590 & 640 & $590 \pm 118$ & 0 \\
\hline $\begin{array}{l}\text { Roots and } \\
\text { Tubers }\end{array}$ & $20 \mathrm{a}$ & $20 a$ & $28 \mathrm{~b}$ & $22 \pm 31$ & $\begin{array}{l}0.00 \text {, where food amount qualified by } \\
\text { letters a and b vary }\end{array}$ \\
\hline $\begin{array}{l}\text { Green Leafy } \\
\text { Vegetables }\end{array}$ & $180 \mathrm{a}$ & $130 \mathrm{~b}$ & $130 \mathrm{~b}$ & $\mid 47 \pm 57$ & $0.00 ”$ \\
\hline Pulses & 20 & 25 & 30 & $25 \pm 25$ & 0 \\
\hline Meat / Fish & 5 & 35 & 80 & $50 \pm 50$ & 0 \\
\hline Carrots & 15 & 20 & 30 & $20 \pm 30$ & \\
\hline Eggs & 10 & 22 & 50 & $32 \pm 40$ & 0.01 \\
\hline $\begin{array}{l}\text { Milk and Milk } \\
\text { Products }\end{array}$ & $25 \mathrm{a}$ & $100 \mathrm{~b}$ & $100 \mathrm{~b}$ & $75 \pm 82$ & $\begin{array}{l}0.00 \text {, where food amount varies as shown } \\
\text { by letters } a \text { and } b\end{array}$ \\
\hline Sugar & $10 \mathrm{a}$ & $25 \mathrm{~b}$ & $25 \mathrm{~b}$ & $20 \pm 11$ & $0.00 ”$ \\
\hline Fats and Oils & 20 & 25 & 30 & $25 \pm 20$ & 0 \\
\hline Fruits & 20 & 43 & 65 & $43 \pm 40$ & 0 \\
\hline Total & 880 & 1012 & 1168 & 1039 & \\
\hline
\end{tabular}

\section{Discussion}

The study found that $88 \%$ of the households consumed maize, $90 \%$ sugar, $92 \%$ vegetables, $26 \%$ fruits, $46 \%$ meat and $4.5 \%$ chicken. This compares favorably with figures obtained by a $24 \mathrm{~h}$ recall study previously done in 5 districts which showed the percentage of households who consumed maize was $91.1 \%$, while $80.5 \%$ consumed sugar, $50 \%$ consumed vegetables and $10 \%$ fruit. This research found, that the low income group only met the FAO recommendations for food consumption of cereals food at $500 \mathrm{~g}$ and green leaves at $50 \mathrm{~g}$ per capita per day, an indication that they lack income to purchase recommended amounts of other foods that are expensive. The middle and high-income groups' diets met the FAO recommendations for cereals foods, green leaves, meat, milk, cooking fat/oil and margarine and eggs, the four animal source foods which the low income diets fell short of meeting.

The significance of difference of foodstuffs consumption among various income groups was calculated using SPSS version 20, and there was significance at $\mathrm{p} \leq 0.05$. People choose to consume food according to interest, budget constraints, to avoid diseases and to the availability of foods. Nutrition educators routinely encourage people to eat more fruits and vegetables as these provide vitamins and minerals such as vitamin A, C, iron and zinc which would otherwise be deficient in various sectors of children and adult populations. It appears that during dietary transitions, there is need for guidelines for good food consumption patterns. Many countries have issued dietary guidelines for the consumption of diverse foods intended to achieve adequate nutrition. Daily consumption of a variety of nutrient dense foods with at least an item from each food group is recommended.

The United States Department of Agriculture (USDA) has categorized recommended foods into five groups which are cereals, vegetables, fruit, dairy and protein source foods (meat, fish, poultry, eggs, nuts and beans). Strategies that promote and facilitate dietary diversification among the poor are essential so that cereal or tuber based diets are complemented with micronutrient rich foods. FAO has recommended improvement of soils for agriculture, small-scale home and community vegetable and fruit gardens; production of small animals such as rabbits, goats, guinea pigs; and implementation 
of large scale commercial vegetable and fruit production; and improvement of storage and food preservation.

\section{Conclusion}

It was noted that income is a major factor influencing consumption. There is significant difference in per capita daily intake of foodstuffs among the three income groups, at $\mathrm{p} \leq 0.05$. The low income group households have low purchasing power for adequate foods. The low income group did not consume the FAO recommended amounts of white bread, rice, meat, eggs, carrots, fresh bananas, butter or margarine, sugar and milk in tea. The low income group cannot meet the FAO and WHO recommended levels of the calculated or tested nutrients $\mathrm{kcl}$, vitamin $\mathrm{A}(\mathrm{RE})$, although they consumed adequate vitamin C. They, therefore, suffer food insecurity and nutrient deficiencies. The middle and high income groups consumed the FAO/ WHO recommended levels of the tested nutrients that are $\mathrm{kcl}$, vitamin $\mathrm{A}(\mathrm{RE})$ and vitamin $\mathrm{C}$.

\section{Recommendations}

Food security and nutrition in households can be improved by:

i. Up-scaling occupations such as small-scale businesses and income, especially among the low income group.

ii. Irrigation equipment and practice should be carried out in arid lands.

iii. There should also be nutrition training for households to consume balanced diet supplying nutrients.

iv. Households should, where possible, develop and maintain kitchen gardens to raise and provide fruit, vegetables, poultry and other small animals.

v. Bio intensive farming approach e.g. use of hanging sacks to plant crops.

vi. Food for work activities.

\section{Acknowledgements}

None.

\section{Conflict of interest}

The author declares no conflict of interest.

\section{References}

1. Poverty and hunger: issues and options for food security in developing countries. USA: A World Bank policy study, The World Bank; 1986.

2. Onyango A, Koski K, Turker K. Food diversity versus breast feeding choice in determining anthropometric status in rural Kenyan Toddlers. Int J Epidemiol. 1998;27(3):484-489.
3. Food and Nutrition: Creating a Well Fed World. Italy: FAO; 1990.

4. Kenya Food Insecurity. USAID; 2010.

5. Pinstrup-Andersen P, Pandya-Lorch R. Prospects for world food security and distribution. Eco-regional approaches for sustainable land use and food production; 1995:89-111.

6. Nutrition and Poverty. Papers from the ACC/SCN 24th Session Symposium Kathmandu. Nutrition Policy Paper No. 16, 1997. p. 69-76.

7. GOK Ministry of Planning and Development. The Planning Bulletin, Millennium Development Goals. 2(1).

8. FAO corporate document repository. Agriculture food and nutrition for Africa.

9. National food balance sheets 2000-2005. Central Bureau of Statistics; 2006.

10. Kenya Demographic and Health Survey. GOK Central Bureau of Statistics; 2003. p. 163-167.

11. Otieno J. Sixteen million Kenyans are living in extreme poverty. All Africa; 2007.

12. Geographic dimensions of wellbeing in Kenya. Who and where are the poor? A constituency level profile. GOK Central Bureau of Statistics; 2005.

13. Barrett CB. Food security and food assistance programs. Handbook of Agricultural Economics. 2002;2:1-49.

14. Food Security in Kenya. Kenya Food Security Steering Group (KFSSG); 2010 .

15. Repositioning Nutrition as Central to Development: A Strategy for Large Scale Action. USA: The World Bank; 2006.

16. Kenyans for Kenya, Daily Nation 2, Nairobi, Africa; 2011.

17. Smith L, Haddad L. Overcoming child malnutrition in developing countries: Past achievements and future choices. Food, agriculture and the environmental discussion paper 30. USA: International Food Policy Research Institute; 2000.

18. Warah R. Zimbabwe evictions a pointer to Africa's chaotic urban growth, says Habitat. East African; 2005.

19. Mucheke B. Slum housing plan calls for resources, proper planning. The Standard February 25th. 2005.

20. Economic Survey. Kenya: GOK; 2002. p. 19-68.

21. Kinyua J. Towards Achieving Food Security in Kenya. Assuring food and nutrition security in Africa by 2020: Prioritizing action, strengthening actors, and facilitating partnerships. Kampala, Uganda, Africa; 2004.

22. Coping without coping: What the poor say about poverty in Kenya. Africa: AMREF/GOK; 1996. 